\title{
Evaluation of the antidepressant-like activity of the methanolic extract of the seeds of Sesamum indicum
}

\author{
Md Rashidur Rahman * (D), Mostakim Sharif, Mohammad Ali and Sheikh Shahriar Rajib
}

\begin{abstract}
Background: The search for novel pharmacotherapy from medicinal plants for central nervous system (CNS) disorders has become of importance since new agents with improved efficacy for more effective therapy are required. Sesamum indicum has been extensively used in Bangladesh and other Indian Subcontinent as medication for various diseases including CNS disorders. It was found to have antioxidant, antitumor, antihypertensive, neuroprotective, hypoglycemic, antimicrobial, anticonvulsant and wound healing activity.

Results: The result showed robust and dose-dependent antidepressant-like activity. There are statistically significant $\left(p^{*}<0.05\right)$ reductions in the duration of immobility time both in forced swimming and tail suspension test. In open field test, measurement of locomotion, defecation and rearing are evaluated. There is statistically significant $\left(p^{*}<0\right.$. 05) increase in locomotion, rearing and defecation of mice compared to control group.

Conclusions: These results clearly demonstrates that methanolic extract of the seeds of Sesamum indicum has potential antidepressant activity and further studies should be conducted to identify, isolate and evaluate its potential active compound responsible for such effect.
\end{abstract}

Keywords: Antidepressant, Depression, Sesame, TST, FST, OFT

\section{Background}

Depression is becoming a rising concern in the current world as almost 450 million people around the world suffer from it according to WHO. Depression along with anxiety is now the most prevalent mental disorders all over the world; together they are responsible for $50 \%$ of psychiatric and substance use disorders [1]. According to some epidemiological studies, more than $20 \%$ of the general populations have at least one of these disorders during their lifetime [2]. Nearly one in four women and one in six men experience depression in their life [3], and up to $65 \%$ of individuals have recurrent episodes of the disorder [4-6]. Now, Depression has been found to be the fourth leading cause of overall disease burden and the leading cause of nonfatal disease burden worldwide [7]. Drugs such as Tricyclic antidepressants, Monoamine Oxidase Inhibitors, Selective Serotonin

\footnotetext{
* Correspondence: mr.rahman@just.edu.bd

Department of Pharmacy, Jessore University of Science \& Technology, Jessore 7408, Bangladesh
}

Reuptake Inhibitors currently is used for the treatment of depression which possess some serious drawbacks like insomnia, weight gain, sedation, anxiety etc. As it is well known that natural source have less side effects and complications [8], our goal was to find a new antidepressant drug of natural origin.

Sesamum indicum Linn. (Pedaliaceae) is an annual shrub with white bell-shaped flowers with a hint of blue, red or yellow with branches or without branches. It is grown for the production of seeds which is rich in oil content. It comes in a variety of colors, cream-white to charcoal-black. Sesame is found in tropical, subtropical, and southern temperate areas of the world, particularly in India, China, South America and Africa. It was found to have antioxidant [9], antitumor [10], antihypertensive [11], neuroprotective [12], hypoglycemic [13], antimicrobial [14], anticonvulsant [15] and wound healing activity [16]. It was also found to prevent high fat diet induced obesity [17]. 


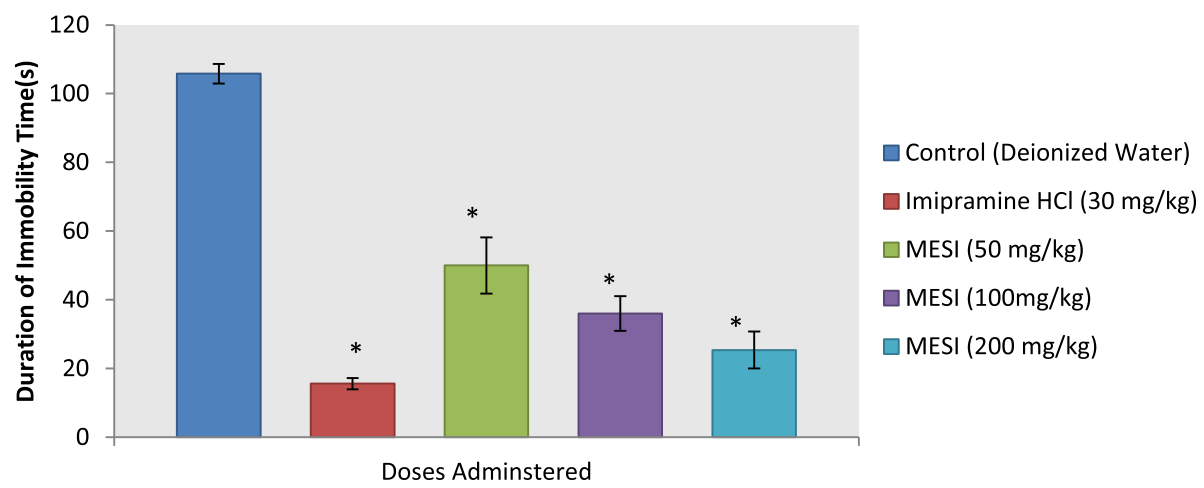

Fig. 1 Graphical presentation of the effect of MESI on immobility time in TST

\section{Materials \& methods}

Collection \& Preparation of extract

Seeds of Sesamum indicum were collected from the local market of Jessore and evaluated for identity and authenticated by the Senior Scientific Officer, Bangladesh National Herbarium, Dhaka, Bangladesh. The Seeds were washed with tap water and then dried under the shade. The seeds then powdered by using mortar and pestle. The powdered seeds then dipped into absolute methanol for 7 days. The extract was filtered and solvent was evaporated using rotary evaporator and crude extract with oily and paste like consistency was obtained.

\section{Experimental animal}

The animals used for this study were male Albino Swiss mice (6-8 weeks and $20-30 \mathrm{~g}$ ). A total of 75 animals were used for this study (25 for each test). The animals used for this study were purchased from Jahangirnagar University, Dhaka. The animals were housed in groups of 5 and were allowed to acclimatize to laboratory conditions for a minimum of 5 days before the time of experimentation. All animals had free access to standard animal feed and clean water and were maintained on a $12 / 12 \mathrm{~h}$ of light/dark cycle. The ambient temperature was $22 \pm 3{ }^{\circ} \mathrm{C}$. All animals used in the study were cared for and treated humanely throughout the study period following international guidelines.

Table 1 Effect of MESI in TST

\begin{tabular}{lll}
\hline Treatment & Doses & Immobility time \\
\hline Deionized water & $01 \mathrm{ml} / \mathrm{mice}$ & $105.8 \pm 2.853$ \\
Imipramine Hydrochloride & $30 \mathrm{mg} / \mathrm{kg}$ & $15.6 \pm 1.631^{*}$ \\
$\mathrm{MESI}$ & $50 \mathrm{mg} / \mathrm{kg}$ & $50.0 \pm 8.156^{*}$ \\
$\mathrm{MESI}$ & $100 \mathrm{mg} / \mathrm{kg}$ & $36.0 \pm 5.05^{*}$ \\
$\mathrm{MESI}$ & $200 \mathrm{mg} / \mathrm{kg}$ & $25.4 \pm 7.718^{*}$ \\
\hline
\end{tabular}

Values are presented as mean \pm SEM $(n=5)$

$P^{*}<0.05$ compared with the control group (Dunnett's test)

\section{Grouping \& Dosing}

There were five groups of animals for each model. All animals were randomly assigned to different groups. Group I received the vehicle (2\% Tween 80 in deionized water) and served as control. Group II received the standard drug imipramine hydrochloride $(30 \mathrm{mg} / \mathrm{kg})$ and served as positive control. The test groups were divided into three groups, III-V, which received increasing doses of the extract at $50 \mathrm{mg} / \mathrm{kg}, 100 \mathrm{mg} / \mathrm{kg}$, and $200 \mathrm{mg} / \mathrm{kg}$, respectively. The different doses of the extract were dissolved in $2 \%$ Tween 80 solution and were administered for 14 days at a fixed time.

\section{Experimental Methods \& Procedures}

All tests were performed in the Pharmacology Laboratory of Department of Pharmacy, Jessore University of Science \& Technology.

\section{Tail suspension test (TST)}

This method was developed by Steru (1985) and is used with slight modifications [18]. This method was employed on the observation that a mouse suspended by the tail shows alternate agitation and immobility which indicates a state of depression. TST induced immobility is reduced by a large number of clinically active and atypical antidepressant effect. A total of 25 mice were treated with control, extract or Imipramine hydrochloride and were placed in the middle of the stand. Two stands, each with a

Table 2 Effect of MESI in FST

\begin{tabular}{lll}
\hline Treatment & Doses & Immobility time \\
\hline Deionized water & $01 \mathrm{ml} / \mathrm{mice}$ & $106 \pm 3.007$ \\
Imipramine Hydrochloride & $30 \mathrm{mg} / \mathrm{kg}$ & $20.8 \pm 1.985^{*}$ \\
MESI & $50 \mathrm{mg} / \mathrm{kg}$ & $56.75 \pm 4.56^{*}$ \\
MESI & $100 \mathrm{mg} / \mathrm{kg}$ & $36.8 \pm 3.153^{*}$ \\
MESI & $200 \mathrm{mg} / \mathrm{kg}$ & $27.8 \pm 2.131^{*}$ \\
\hline
\end{tabular}

Values are presented as mean \pm SEM $(n=5)$

$P^{*}<0.05$ compared with the control group (Dunnett's test) 


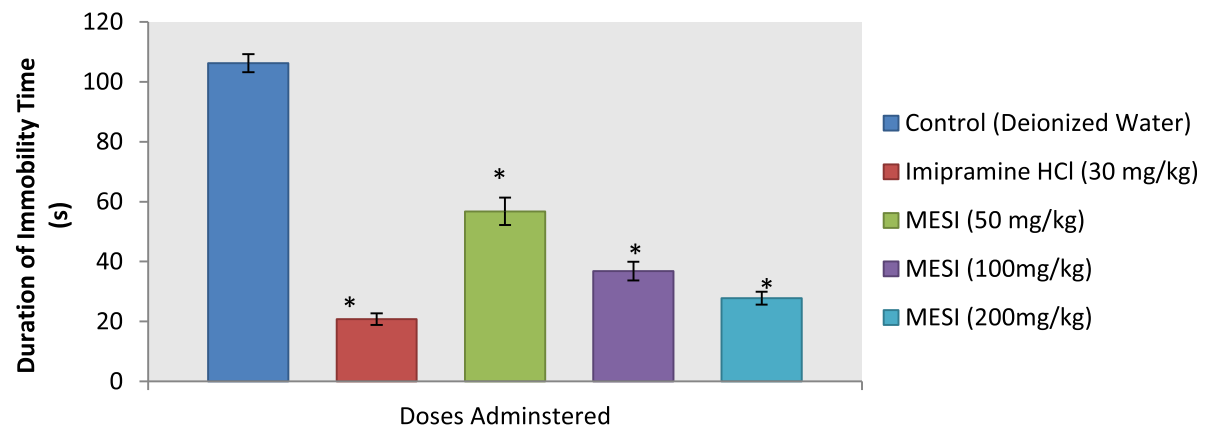

Fig. 2 Graphical presentation of the effect of MESI on immobility time in FST

clamp located $22 \mathrm{~cm}$ from the floor, were placed at intervals of $23 \mathrm{~cm}$. A mouse was hung $5 \mathrm{~cm}$ from the end of its tail on a stand, and observed for $6 \mathrm{~min}$. Immobility time was evaluated by observers.

\section{Forced swimming test (FST)}

This method was developed by Porsolt (1977) and is employed with some modifications [19]. The male mice were forced to swim individually in a transparent glass container $(20 \mathrm{~cm}$ in diameter and height of $40 \mathrm{~cm})$ containing fresh water of $19 \mathrm{~cm}$ height which was maintained at $25^{\circ} \mathrm{C}\left( \pm 3{ }^{\circ} \mathrm{C}\right)$ and allowed to swim for $5 \mathrm{~min}$. The mice were judged to be immobile when they remained floating without struggling, and making movements necessary only to keep their heads above the water. The total duration of immobility was recorded using a stop watch.

\section{Open field test (OFT)}

The OFT was carried out in order to rule out any non-specific locomotor effect the extract might possess. The locomotor activity test was performed according to the method of Carlini (1986) with slight modifications [20]. Mice were placed in an open field apparatus composed of an arena divided into 64 approximately equal areas. For open field observations, each mouse was individually placed in the center of the arena $15 \mathrm{~h}$ after the last treatment. The locomotion (number of line crossings), rearing frequencies (number of times seen standing on hind legs), and number of defecations within 5 min was observed and calculated.

\section{Statistical analysis}

The results obtained from these tests were statistically evaluated using SPSS 23.0 version software. The statistical analysis was done by one-way analysis of variance (ANOVA) followed by Dunnet's post hoc test. The results were presented as mean value $\pm \operatorname{SEM}(n=5)$. The difference between group was considered significant at a level of $\mathrm{p}^{*}<0.05$. The statistically significant results are marked with a star $\left(^{*}\right)$ sign in the table as well as in the graph.

\section{Results}

Effect of MESI in TST

The extract reduced the duration of immobility time in the tail suspension test (Table 1 and Fig. 1). Dunnet's Post hoc analysis confirmed that the extract significantly decreased the immobility time in comparison to the control group $\left(p^{*}<0.05\right)$.

\section{Effect of MESI in FST}

The extract significantly reduced the duration of immobility time in the forced swimming test (Table 2 and Fig. 2). Dunnett's post hoc analysis demonstrated that the test treatments significantly decreased the immobility time in comparison to the control group $\left(p^{*}<0.05\right)$.

\section{Effect of MESI in OFT}

The effect of treatment with absolute methanol seed extract of Sesamum indicum on the locomotor behavior of mice in the OFT is presented in Table 3. The outcome of the test revealed that the doses of the extract that were able to display antidepressant-like response. The total square crossing, rearing and defecation are recorded. The defecation, locomotion, and rearing increased with increasing dose compared to control group as shown in Figs. 3, 4 and 5.

\section{Discussion}

Behavioral despair based tests

The duration of immobility has been shown to be reduced by treatment with antidepressant drugs and a statistically

Table 3 Effect of MESI in OFT

\begin{tabular}{lllll}
\hline Treatment & Doses & Locomotion & Rearing & Defecation \\
\hline $\begin{array}{l}\text { Deionized } \\
\text { water }\end{array}$ & $01 \mathrm{ml} / \mathrm{mice}$ & $98.4 \pm 7.07$ & $25.4 \pm 1.435$ & $1.2 \pm 0.2$ \\
$\begin{array}{llll}\text { Imipramine } \\
\text { Hydrochloride }\end{array}$ & $30 \mathrm{mg} / \mathrm{kg}$ & $208.6 \pm 13.58^{*}$ & $35.8 \pm 1.428^{*}$ & $3.4 \pm 0.4^{*}$ \\
MESI & $50 \mathrm{mg} / \mathrm{kg}$ & $129.75 \pm 5.12^{*}$ & $27.75 \pm 0.854$ & $1.75 \pm 0.25$ \\
MESI & $100 \mathrm{mg} / \mathrm{kg}$ & $137.2 \pm 9.015^{*}$ & $30.8 \pm 1.356^{*}$ & $2.8 \pm 0.49^{*}$ \\
MESI & $200 \mathrm{mg} / \mathrm{kg}$ & $167.4 \pm 5.38^{*}$ & $34.2 \pm 1.281^{*}$ & $3.4 \pm 0.245^{*}$ \\
\hline
\end{tabular}

Values are presented as mean $\pm \operatorname{SEM}(n=5)$

$P^{*}<0.05$ compared with the control group (Dunnett's test) 


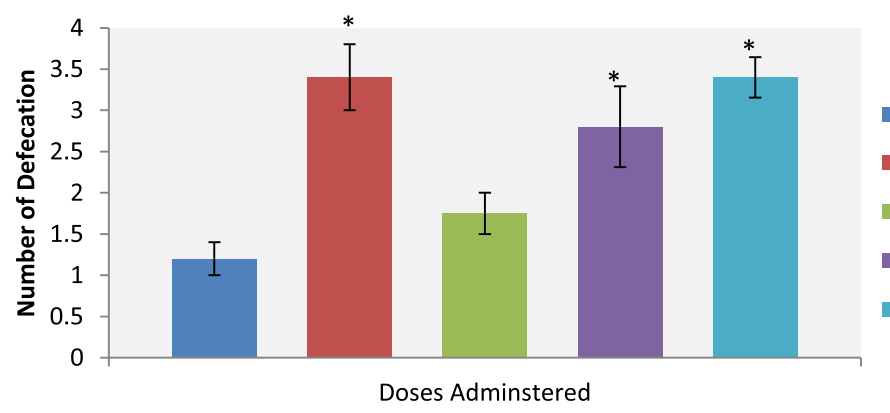

- Control (Deionized Water)

- Imipramine $\mathrm{HCl}(30 \mathrm{mg} / \mathrm{kg}$ )

MESI (50 mg/kg)

- MESI (100 mg/kg)

MESI (200 mg/kg)

Doses Adminstered

Fig. 3 Graphical presentation of the effect of MESI on Defecation

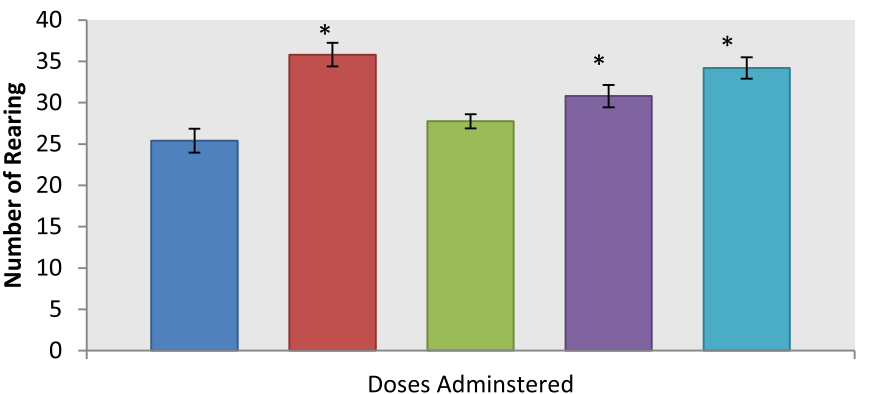

$\square$ Control (Deionized water)

- Imipramine $\mathrm{HCl}(30 \mathrm{mg} / \mathrm{kg}$ )

$\square \mathrm{MESI}(50 \mathrm{mg} / \mathrm{kg})$

口 MESI $(100 \mathrm{mg} / \mathrm{kg})$

$\square \operatorname{MESI}(200 \mathrm{mg} / \mathrm{kg})$

Fig. 4 Graphical presentation of the effect of MESI on Rearing

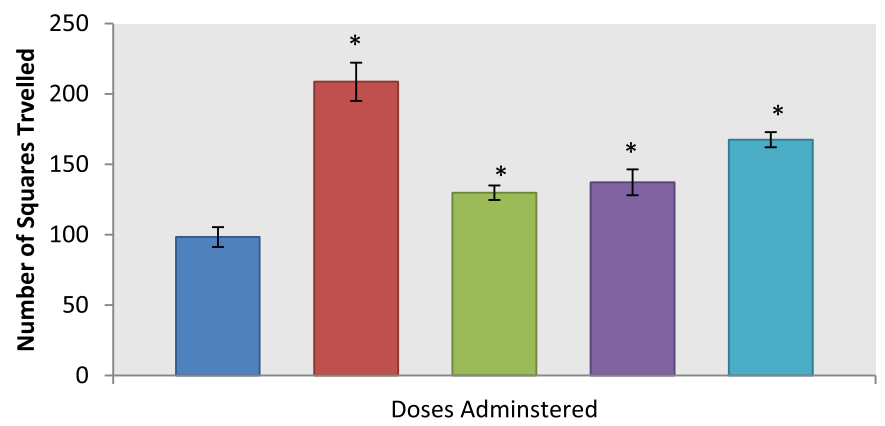

$\square$ Control (Deionized Wter)

- Imipramine $\mathrm{HCl}(30 \mathrm{mg} / \mathrm{kg})$

$\square$ MESI $(50 \mathrm{mg} / \mathrm{kg}$ )

$\square$ MESI (100 mg/kg)

$\square$ MESI (200 mg/kg)

Fig. 5 Graphical presentation of the effect of MESI on Locomotion 
significant correlation was found between the clinical efficacy of antidepressant drugs and their potency in both models $\left(p^{*}<0.05\right)$.

After administering the test dose of 50, 100 and 200 $\mathrm{mg} / \mathrm{kg}$ of seed extract show a statistically significant antidepressant-like activity in the $\operatorname{TST}\left(p^{*}<0.05\right)$. The MESI exhibited a reduction in the time of immobility at the dose of 50 and $100 \mathrm{mg} / \mathrm{kg}$. Finally, $200 \mathrm{mg} / \mathrm{kg}$ was found best compared to controlled group. In FST; the seed extract displayed a notable reduction in the duration of immobility in comparison to the control animals, which is suggestive of a considerable antidepressant-like activity. The statistically significant reduction in immobility was seen at all doses. This indicates an increase in the concentration of the active principles or in the ability to neutralize the effect of inhibitors with increasing dose of the extract.

The variability in the response of different antidepressants in these models, however, indicates potentially different substrates and neurochemical pathways mediating performance in these tests. The highest percent reduction in time of immobility was seen in the TST than FST, possibly due to the fact that any possible confounds induced by stressful hypothermic exposure in the FST are not present in TST.

\section{Effect on locomotor activity in the OFT}

In this study, it was demonstrated that the crude extract of Sesamum indicum seeds significantly alter the spontaneous locomotor activity of mice during the OFT evaluated by statistical analysis $\left(p^{*}<0.05\right)$. It is indicative that increase in dose of extract increases the number of squares travelled or passively locomotion. Although compared to imipramine hydrochloride increase in locomotion is not significant but compared to controlled group increase in locomotion is significant and this implies that the extract have active ingredient that is responsible for antidepressant-like activity.

\section{Conclusion}

Based on the findings obtained from this study, it is safe to infer that the methanolic extract of the seeds of Sesamum indicum possesses a significant antidepressant-like activity. This is indicated by the decrease in the duration of immobility in established behavioral despair based models of depression. The antidepressant-like effect of the methanol fractions of the extract as observed in the TST and FST were found statistically significant. The outcome of OFT indicates that effect on locomotor activity at all extract doses, the antidepressant- like activity observed is not caused by a non-specific motor stimulation. Hence, further studies on this plant should be pursued in order to reap the best possible therapeutic benefits.

\section{Abbreviations}

FST: Forced Swimming Test; MESI: Methanolic Extract of the Seeds of Sesamum indicum; OFT: Open Field Test; TST: Tail Suspension Test

\section{Acknowledgements}

The authors are grateful to the Chairman, Department of Pharmacy, Jessore University of Science \& Technology for permitting us to use the facilities of Pharmacology laboratory.

\section{Funding}

This research did not receive any specific grant from funding agencies in the public, commercial, or not-for-profit sectors.

\section{Availability of data and materials}

The datasets used and analysed during the current study are available from the corresponding author on reasonable request.

\section{Authors' contributions}

MRR designed, coordinated and analyzed all the experiments. MS, MA and SSR have done all the experiments. MS have done the statistical analysis and wrote the manuscript. All authors read and approved the manuscript.

Ethics approval and consent to participate

All Experimental rules were approved by the Ethical Review Committee, Faculty of Biological Sciences, Jessore University of Science \& Technology, Jessore-7408, Bangladesh.

\section{Competing interests}

The authors declare no conflict of interest. Authors are solely responsible for the writing and content of this article.

\section{Publisher's Note}

Springer Nature remains neutral with regard to jurisdictional claims in published maps and institutional affiliations.

Received: 3 January 2018 Accepted: 27 December 2018 Published online: 17 January 2019

\section{References}

1. Whiteford HA, Degenhardt L, Rehm J, Baxter AJ, Ferrari AJ, Erskine HE, et al. Global burden of disease attributable to mental and substance use disorders: findings from the global burden of disease study. Lancet. 2010; 382:1575-86.

2. Pedersen $C B$, Mors $\mathrm{O}$, Bertelsen $\mathrm{A}$, Waltoft $\mathrm{BL}$, Agerbo $\mathrm{E}$, McGrath JJ, et al. A comprehensive nationwide study of the incidence rate and lifetime risk for treated mental disorders. JAMA Psychiatry. 2014:71:573-81.

3. Kessler RC, Birnbaum H, Bromet E, Hwang I, Sampson N, Shahly V. Age differences in major depression: results from the National Comorbidity Survey Replication (NCS-R). Psychol Med. 2010;40:225-37.

4. Eaton WW, Shao H, Nestadt G, Lee BH, Bienvenu OJ, Zandi P. Populationbased study of first onset and chronicity in major depressive disorder. Arch Gen Psychiatry. 2008;65:513-20.

5. Monroe SM, Harkness KL. Recurrence in major depression: a conceptual analysis. Psychol Rev. 2011;118:655-74.

6. Yiend J, Paykel E, Merritt R, Lester K, Doll H, Burns T. Long term outcome of primary care depression. J Affec Disord. 2009;118:79-6.

7. Ustun TB, Ayuso-Mateos JL, Chatterii S, Mathers C, Murray CJ. Global burden of depressive disorders in the year 2000. British J of Psychiatry. 2004;184 386-92.

8. Zhang ZJ. Therapeutic effects of herbal extracts and constituents in animal models of psychiatric disorders. Life Sci. 2004;75:1659-99.

9. Kumar P, Yadav V, Chaurasia V, Rao VC. Pharmacological investigation of anticonvulsant activity of Sesamum indicum Linn. 50\% ethanol leaves extract. Research J Pharm and Tech. 2011:4:1822-4.

10. Vishwanath HS, Anilakumar KR, Harsha SN, Khanum F, Bawa AS. In vitro antioxidant activity of Sesamum indicum seeds. Asian J Pharm Clin Res. 2012;5:56-60.

11. Xu H, Wen YP, Zhao W, He Q. In Vitro antitumour activity of Sesamum indicum Linn flower extracts. Tropical J of Pharmaceutical Res. 2010; 455-62. 
12. Jamarkattel-Pandit N, Pandit NR, Kim MY, Park SH, Kim KS, Choi H, Kim H, Bu Y. Neuroprotective effect of defatted sesame seeds extract against in vitro and in vivo ischemic neuronal damage. Planta Med. 2010;76:20-6.

13. Seukep JA, Fankam AG, Djeussi DE, Voukeng IK, Tankeo SB, Noumdem JA, et al. Antibacterial activities of the methanol extracts of seven Cameroonian dietary plants against bacteria expressing MDR phenotypes. Springerplus. 2013;2:363.

14. Bhuvaneswari P, Krishnakumari S. Antihyperglycemic potential of Sesamum indicum (Linn) seeds in Streptozotocin induced diabetic rats. Int J of Pharm Pharm Sci. 2012;4:527-31.

15. Gilani AU, Aftab K. Presence of acetylcholine-like substance(s) in Sesamum indicum. Arch Pharm Res. 1992;15:95-8.

16. Kiran K, Asad M. Wound healing activity of Sesamum indicum $L$ seed and oil in rats. Indian J of Experimental Biol. 2008;46:777-82.

17. Yuan H, Chung S, Ma Q, Ye L, Piao G. Combination of deep sea water and Sesamum indicum leaf extract prevents high-fat diet-induced obesity through AMPK activation in visceral adipose tissue. Exp Ther Med. 2016: 338-44

18. Steru L, Chermat R, Thierry B, Simon P. The tail suspension test: a new method for screening antidepressants in mice. Psychopharmacol. 1985;85: 367-70.

19. Porsolt RD, Bertin A, Jalfre M. Behavioural despair in mice: a primary screening test for antidepressants. Acrh Inter Pharmacodyn Ther. 1977;229: $327-36$

20. Carlini EA, Contar JD, Silva-Filho AR, Da Silveira-Filho NG, Frochtengarten ML, Bueno OF. Pharmacology of lemongrass (Cymbopogon citratus Stapf). I. Effects of teas prepared from the leaves on laboratory animals. J Ethnopharmacol. 1986;17:37-64.

\section{Submit your manuscript to a SpringerOpen ${ }^{\circ}$ journal and benefit from:}

- Convenient online submission

- Rigorous peer review

- Open access: articles freely available online

- High visibility within the field

- Retaining the copyright to your article

Submit your next manuscript at $\boldsymbol{\nabla}$ springeropen.com 